\title{
College English Writing Teaching Design Based on Constructivist Mode
}

\author{
Jingyu Liu \\ Foreign Language School, Shenyang Aerospace University, Shenyang, China \\ Email: jyliudiana@126.com
}

Received 14 January 2015; accepted 8 February 2015; published 10 February 2015

Copyright (C) 2015 by author and Scientific Research Publishing Inc.

This work is licensed under the Creative Commons Attribution International License (CC BY). http://creativecommons.org/licenses/by/4.0/

(c) (i) Open Access

\begin{abstract}
Constructivist theory, a key branch of cognitive psychology, is universally recognized as the theoretical basis for innovating traditional teaching. This paper attempts to apply constructivism to writing education, which will be used to help guide writing teaching design and class construction, in order to explore and discover a proper and student-tailored writing class teaching mode.
\end{abstract}

\section{Keywords}

\section{Constructivism, Writing, Teaching Design, Writing Class Mode}

\section{Introduction}

Constructivist theory has long been exerting its great influence throughout the world on all fields, especially teaching and classroom. The $21^{\text {st }}$ century has witnessed a tremendous change in China's education, which has experienced the transformation from knowledge-cramming-oriented teaching to education which is oriented by training students' innovation and integral qualities. In order to satisfy such needs, constructivism-guided teaching modes and methods have been applied increasingly to modern teaching writing practice. This paper is aimed at the exploration of college English writing class modes and teaching methods based on constructivism.

\section{Constructivist Learning Theory and Teaching Mode}

\subsection{Learning Theory}

According to constructivism, learners take to acquiring their knowledge about the outside world in the process of mutual interaction with their surroundings, developing their own cognitive structure (Guo Xuan, 2006). The theory emphasizes the central position of the students. It requires the students' role transformation from stimu- 
lated passive receivers and objects into subjects processing knowledge and active constructors of meanings; as well as the teachers' part from mere knowledge givers into helpers and promoters to students. This will help prompt the effective revolution of the traditional teaching concepts, modes and methods.

\subsection{Teaching Mode}

Under the guidance of learning theory, elements in learning environment will be fully utilized to help students build their knowledge and meanings. In this mode, the learning environment includes circumstances, cooperation, conversation and construction. Teaching course involves teachers, students, teaching materials and media etc. whose functions are in essence different from the traditional ones. Students will become active, while teachers will be organizers and supervisors (Cruickshank, D. R. et al., 2006). Teaching materials will not be the only learning content, but something students feel like pursuing. Media will also be the cognitive instruments to create situations, cooperate and communicate for students and instructors rather than mere means and methods for teachers.

\subsection{Teaching Methods}

Teaching methods guided by constructivism involve three types, namely, Scaffolding Instruction, Anchored Instruction and Random Access Instruction, the first two of which are applied in this research.

Scaffolding Instruction can trace its origin back to the Zone of Prozimal Development Theory proposed by the famous former Soviet psychologist Vygotsky (Liu Dianzhong, 2007). This theory holds the distance between children's actual level of solving problems independently (the first development) and their potential level of settling problems under instructors' guidance (the second development) as the "Zone of Prozimal Development" (See Figure 1). Scaffolding teaching method stresses learning theme, around which teachers construct conceptual framework in regard to. With the help of tutors, students improve within the frame to achieve the final target of knowledge construction. In writing, teachers constantly lead students from one writing level up to another higher one. For instance, learners can be given a theme, "My hometown", through which instructors can combine the previous description type with the new point, exposition, to enable students to grasp the new knowledge while mastering the old one, raising writing skills step by step.

Anchored Instruction needs teachers to provide infectious real events and problems in class, which are compared to "anchor" (Liu Yang, 2005). Once these events and problems are set, the teaching contents and progress will be "anchored". The materials for writing projects are mostly originated from real-life events. Writing comes from and above real life. Teachers need to lead students to pay close attention to what is going on around them. For example, when the topic "Introduction of Chinese traditional festival" is given, it is not difficult to recall some rituals we observe for each custom (See Figure 2).

Random Access Instruction aims to let learners have a comprehensive and intensive command of all knowledge and skills through many "accesses" to the same contents. Learning the same content should be done many times, in different contexts, with various targets and with a view to diverse sides of the questions (Gao Wen, 1999). This mode will enable learners to get a new understanding of knowledge (Xu lihua, 2012).

In writing class, the writing teaching courses based on constructivism should be involved with such teaching links as context-setting, cooperative learning, exchange and discussion and meaning-constructing, etc.

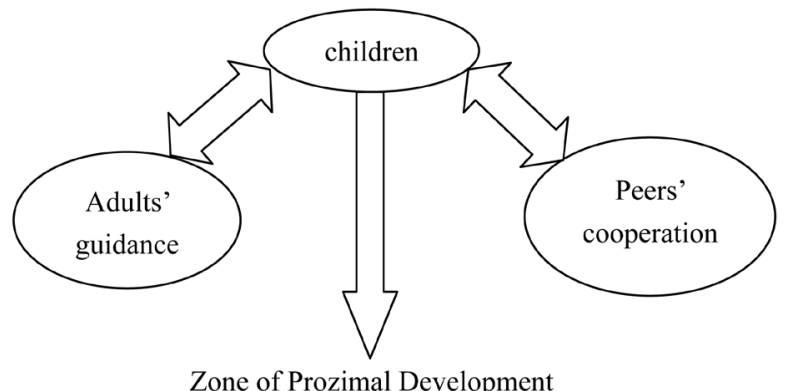

Figure 1. Zone of prozimal development. 


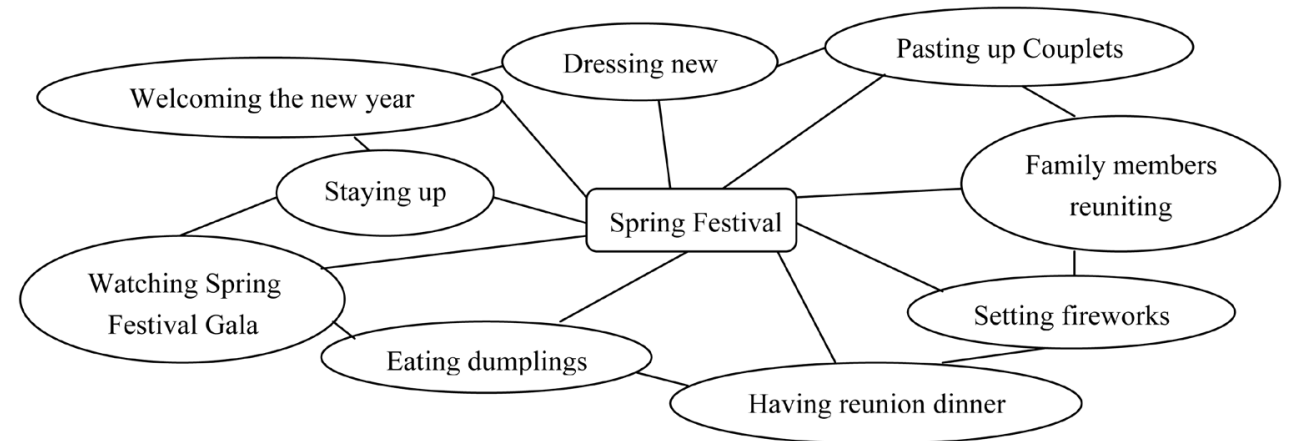

Figure 2. Example "spring festival”.

\section{Design Principle for Writing Course}

\subsection{Learners' Position}

The students-centered concept in teaching design is the core principle of constructivism, which is embodied by the three elements as pioneering spirits, knowledge exhibition and self-feedback realization (Gagnon, G. W. et al., 2001). In writing, teachers should help students take their own experiences and ideas as the original material, and integrate with writing knowledge input from the writing course, creating their own unique essays. Meanwhile, learners can review and reread their works to achieve self-feedback.

\subsection{Learning Context}

Constructivism emphasizes the great influence of context on meanings, and believes the close relationship between learning and certain social and cultural background. Learning context is an indispensable factor in writing a good article.

\subsection{Cooperative Learning}

The interaction and cooperation between learners and their surroundings are key to meaning construction. Under teachers' guidance and organization, students get together to do discussions, communication and debate about what and how to write and so on, enabling the whole group (including teachers and each student) to share all ideas and intellect.

\subsection{Learning Environment}

Constructivism stresses the careful design of learning environment rather than the teaching one. It is where learners can explore freely and study independently (Dick, W. et al., 2005). Our writing course design makes full use of computers and the Internet to create a learning website for the students to seek materials, enjoy works of high quality, post their own articles and evaluate and learn from others, providing a good learning atmosphere for the course as well as offering more opportunities $f$ or learners to interact liberally and actively.

\subsection{Learning Materials}

All resources in the course need to support learners' active exploration and knowledge acquisition, not merely for instructors' presentation (Rowntree, D., 1990). Our teachers' job is to give necessary and adequate aid and instruction as to where, how and how to effectively utilize these writing resources.

\subsection{Learning Aims}

The whole course design should be centered on Meaning Construction, which means the ultimate aim for studying is to accomplish methods acquisition (Jiang Mei, 2007). Each writing course will involve methods introduction, theme discussion, individual or group practice, etc., achieving meaning construction for learners. 


\section{Processes for Writing Course Teaching Design Based on the Principle}

\subsection{Fixing Learning Themes}

This writing course has its them that is to start from a whole and spread to every unit, lead students to both grasp the overall writing skills and master the writing essence, assisted by practice, achieving a refined and perfect essay.

\subsection{Creating Learning Context}

In writing, it is easy to create a real-life situation. The task of the teacher is to ask students to observe and pay close attention to their surroundings. Just take one of the courses for example. The job of this writing course is to instruct the students to master the essay of description type and one topic is "Description of my dormitory". Learners are asked to reflect their dorms following the questions: "What can be seen as a whole when the door is opened?”, "What are those following the order of up-down and left-right ?”, "What impression can you get from the view of your dorm?” etc. Through these real questions and corresponding answers, together with true works and some slides, exhibitions and pictures, the teacher helps build the learning context for description study, enabling students to realize the meaning construction and complete their own works.

\subsection{Selecting Learning Materials}

As to learning materials, besides the resources I carefully select to offer to students in class, I also post assorted adequate necessary high-quality works and writing methods on the Internet. In addition, I guide and assist students to learn how to choose and utilize writing materials while studying on- and off-line.

\subsection{Designing Learning Methods}

We stress students-centered, teacher-aided independent learning process (Zhu Qi, et al., 2007). In the design, the author prepares a concept frame for the students, which is shown in website courseware. Students need to exercise their initiative and creativity to conduct special operation, analysis, discussion and presentation. Teacher needs to offer feedback, comment and guidance, letting learners master writing modes, methods and so on at its source.

\subsection{Designing Learning Environment}

The writing course for this semester is held in multimedia classroom, with adequate space and free and open atmosphere as well as multimedia equipment like computers, slide projectors etc.. Students can conduct mutual negotiations, group discussions, individual design and display, thus improving and perfecting their own writing skills and works.

\subsection{Designing Evaluation of Learning Effect}

Our writing course involves two individual evaluations. One is to let students assess and grade their own achievement, including conception, outline-making, writing process, correction and self-feedback. The other is to have students fill in a summary form about this writing lesson, making qualitative evaluation on their mastering writing knowledge and skills, their attitudes and methods, as well as their shortcomings and improvement, etc.

\subsection{Designing Intensive Training}

The intensive training of the writing lesson contains input and output. Input means during the before-and-after class time students should read, appreciate, digest and absorb, study and imitate large amounts of excellent famous works. Output is designed to arouse students' interest and desire in writing through the input, enabling them to construct and create their own inspiration and good works.

\section{After-Teaching Considerations}

\subsection{Teachers' Leading Role and Position}

Just as a play is completed by the cooperation of the director and actors, a course is accomplished by the joint 
efforts of the teacher and students. The supervision of a teacher and the study of students are to a course what the guidance of a director and the performance of actors to a play. The writing course education based on the constructivist principle implies the heavier responsibilities, the greater role and the higher position of the teacher (Dou Shude, 2009). This writing course displays the author's careful preparation before lesson, enlightenment and organization during the course, and feedback and complement after class, showing the teacher's leading role and position.

\subsection{Real Learning Context}

Learning is the process in which learners actively build the objective world, which requires the real-life materials and prototypes in class (Li Qun, 2003). However, if the materials, without the teacher's plan and design, are presented to students disorderly, study will become aimless and blind exploration, communication and discussion will turn to boundless free talk, and the meaning construction will be in vain, resulting in chaotic teaching activities and situations, which the author experienced previously. Accordingly, in this writing course design, it takes lots of time to collect and organize and design the resources and courseware, thus conducting the writing course well and smoothly.

\subsection{Applicability of the Constructivist Teaching Mode}

The writing course is of strong practicality, which can be applied by the constructivism. But those with emphasis on theoretical and abstract knowledge should not be acquired from direct experiences. Consequently, teachers are expected to select teaching methods and teaching modes in accordance with actual teaching conditions in the course design. The teaching and learning theories should be applied to pedagogical practice tailored to diverse lessons and individuals.

\section{Conclusion}

In conclusion, concerning the teaching modes and instructing methods, constructivism revolutionizes the traditional teaching patterns. However, constructivist theory must go through its development and refinement in practice, and at the same time, it should be combined with other theories and patterns or modes in order to seek for better teaching methods and learning instructions for promising future college English writing education as well as college English education.

\section{Acknowledgements}

At the point of finishing this paper, I'd like to express my sincere thanks to all those who have lent me hands in the course of my writing this paper. First of all, I'd like to take this opportunity to show my sincere gratitude to my supervisor, Mr. Li Haiping, who has given me so much useful advices on my writing, and has tried his best to improve my paper. Secondly, I'd like to express my gratitude to my friends who offered me references and information on time. Last but not the least, I'd like to thank those leaders, teachers and working staff especially those in the School of Foreign Languages. Without their help, it would be much harder for me to finish my study and this paper.

\section{References}

Cruickshank, D. R., Jenkin, D. B., \& Metcalf, K. K. (2006). The Act of Teaching. New York: McGraw Hill.

Dick, W., Lou, C., \& Carey, J. O. (2005). The Systematic Design of Instruction. New York: Pearson.

Dou, S. D. (2009). Constructivist Classroom Teaching Mode under the New Education Conception. Journal of Yangtze Normal University, 6, 101-103.

Gagnon, G. W., \& Dan Collay, M. (2001). Design for Learning: Six Elements in Constructivist Classrooms. California: Corwin Press, Inc.

Gao, W. (1999). Characteristics of Constructivist Learning. Foreign Educational Material, 1, 35-39.

Guo, X. (2006). Discussion on the Origins and Influences of Constructivism Learning Theory. Journal of Ili Normal University, $1,52-56$.

Jiang, M. (2007). The Application of Constructivism Learning Theory in the Teaching of "The Introduction of Sociology”. 
Journal of Beijing Electronic Science and Technology Institute, 3, 66-69.

Li, Q. (2003). Constructivism Learning Theory and College Educational Reform. Journal of Henan Vocation-Technical Teachers University, 4, 36-39.

Liu, D. Z. (2007). The “Zone of Prozimal Development” Theory and English Teaching. College English (Academics), 2, 3640.

Liu, Y., \& Zhong, Z. X. (2005). On Anchored Instruction Mode. Jiang Xi Education and Science Development, 2, 51-54.

Rowntree, D. (1990). Teaching Through Self-Instruction: How to Develop Open Learning Materials. New York: Kogan Page.

Xu, L. H. (2012). Application of Random Access Instruction Teaching Mode to College English Intensive Teaching. Shanxi Jiaoyu, Gaojiao, 1-2, 89-90.

Zhu, Q., \& Qi, J. Y. (2007). Design of CAI Based on the Constructivism Learning Theory. Journal of Jixi University, 4, 8285. 
Scientific Research Publishing (SCIRP) is one of the largest Open Access journal publishers. It is currently publishing more than 200 open access, online, peer-reviewed journals covering a wide range of academic disciplines. SCIRP serves the worldwide academic communities and contributes to the progress and application of science with its publication.

Other selected journals from SCIRP are listed as below. Submit your manuscript to us via either submit@scirp.org or Online Submission Portal.
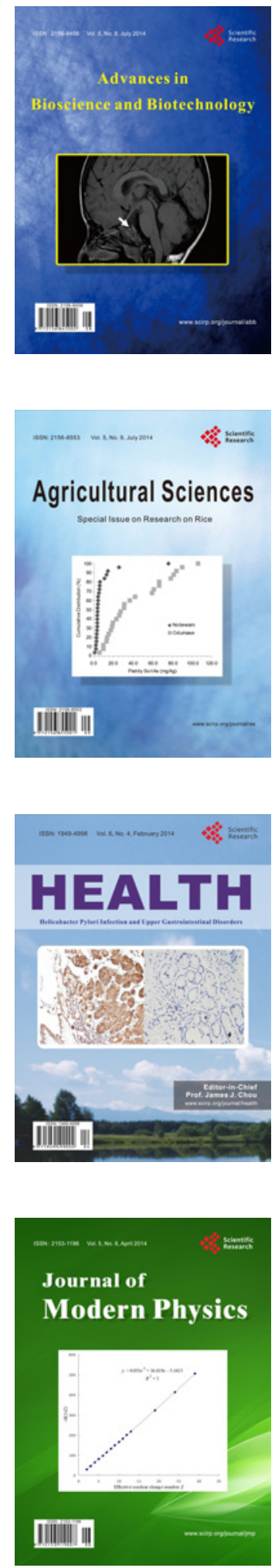
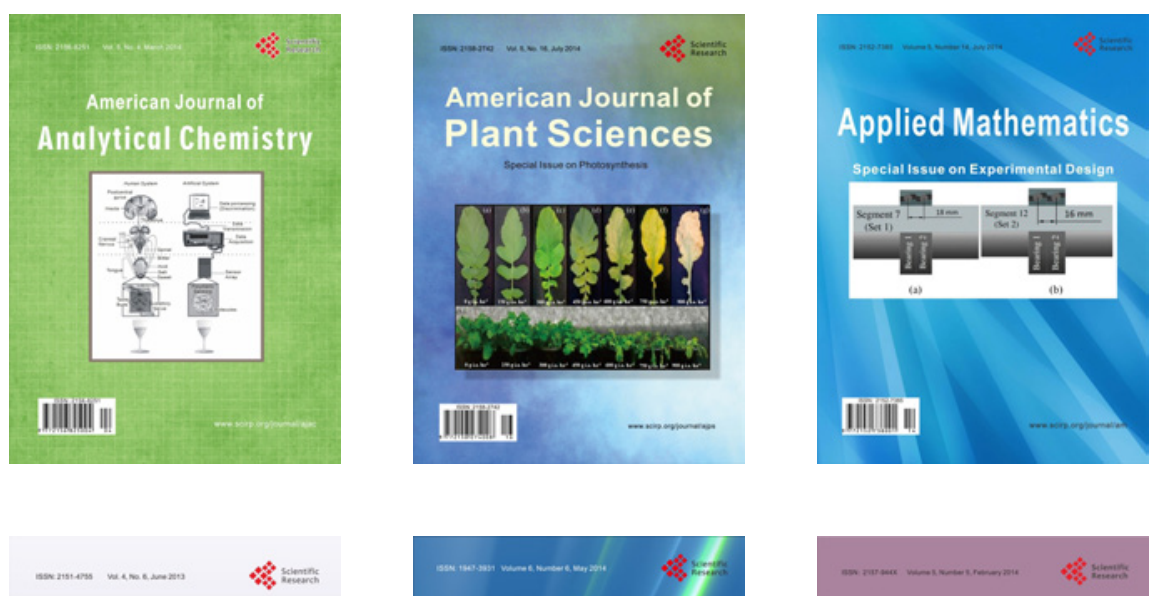

Creative Education
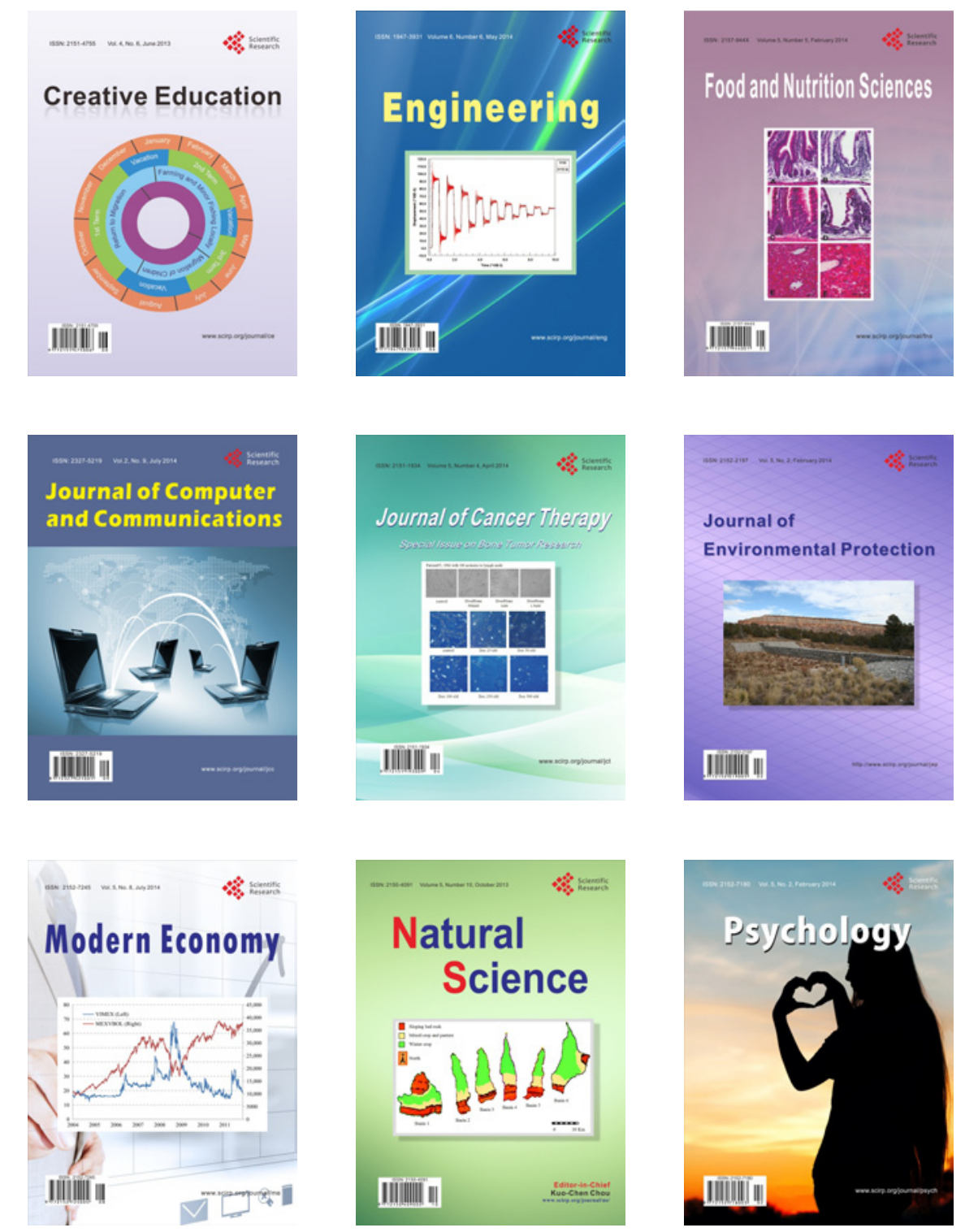